\title{
TINJAUAN HUKUM ISLAM TERHADAP \\ PELAKSANAAN PERWAKAFAN TANAH MILIK DI \\ MASJID AL-MUKMIN DESA KARANGSARI, \\ KECAMATAN JATIYOSO KABUPATEN \\ KARANGANYAR
}

\author{
Taryanto \\ Munifah \\ Universitas Nahdlatul Ulama Surakarta
}

\begin{abstract}
Abstrak
Penelitian ini bertujuan untuk mengetahui tinjauan hukum Islam terhadap pelaksanaan perwakafan tanah. Penelitian ini merupakan penelitian lapangan, yang dilakukan di Masjid Al Mukmin dan KUA Kecamatan Jatiyoso Kabupaten Karanganyar. Sumber data yang digunakan menggunakan wawancara, observasi, dan dokumentasi. Hasil penelitian menunjukkan bahwa sesuai dengan Ketentuan Pasal 18 Peraturan Menteri Agama Nomor 1 Tahun 1978 maka penyeslesaian administrasi perwakafan tanah milik yang di atur dalam peraturan ini dibebaskan dari biaya kecuali biaya meterai. Kenyataannya di KUA Kecamatan Jatiyoso selaku PPAIW tidak memungut biaya kecuali para pihak yang mewakafkan tanahnya hanya dibebani biaya materai. Ini berarti mekanisme tatacara yang sudah diatur dalam Peraturan Pemerintah No 28 Tahun 1977 dan beragam peraturan pelaksanaan lainnya sebagian besar sudah dilaksanakan oleh para pihak yang mendaftarkan tanah miliknya untuk diwakafkan kepada pihak lain. Dengan demikian pelaksanaan perwakafan tanah milik yang diatur dalam Peraturan Pemerintah No 28 Tahun 1977 itu sudah sesuai dengan aturan dalam hukum Islam yaitu ada wakif, nadzir, benda yang diwakafkan, serta ikrar wakaf/ sighot.
\end{abstract}

Kata kunci: Wakaf, Hukum Islam 


\section{Abstract}

This research aims to find out the review of Islamic law on the implementation of land acquisition. This research is a field study, conducted at Masjid Al Mukmin and KUA Jatiyoso District of Karanganyar Regency. Data sources are used using interviews, observations, and documentation. The results showed that in accordance with Article 18 of The Minister of Religious Affairs Regulation No. 1 of 1978, the administration of property property stipulated in this regulation is exempt from fees except seal fees. In fact, in Kua Jatiyoso Subdistrict as PPAIW does not charge fees unless the parties who represent the land are only burdened with stamp duty costs. This means that the procedures that have been regulated in Government Regulation No. 28 of 1977 and are based on other implementation regulations have mostly been implemented by the parties who register their land to be represented to other parties. Thus, the implementation of property representation stipulated in Government Regulation No. 28 of 1977 is in accordance with the rules in Islamic law, namely wakif, nadzir, objects that are represented, and pledge waqf/ sighot.

Keywords: Waqf, Islamic Law

\section{A. PENDAHULUAN}

Sistem hukum di setiap masyarakat memiliki sifat, karakter, dan ruang lingkupnya sendiri. Begitu juga halnya dengan sistem hukum dalam Islam. Islam memiliki sistem hukum sendiri yang dikenal dengan sebutan hukum Islam. Ada beberapa istilah yang terkait dengan kajian hukum Islam, yaitu syariah, fikih, ushul fikih, dan hukum Islam sendiri. ${ }^{1}$

Istilah syariah, fikih, dan hukum Islam sangat populer di kalangan para pengkaji hukum Islam di Indonesia. Namun demikian, ketiga istilah ini sering dipahami secara tidak tepat, sehingga ketiganya terkadang saling tertukar. Untuk itu, di bawah ini akan dijelaskan masing-masing dari ketiga istilah tersebut dan hubungan antar ketiganya, terutama hubungan antara

${ }^{1}$ Marzuki, Tinjauan Umum Hukum Islam, http://www.staffnew.uny.ac.id /upload/132001803, Senin, 09 April 2018, 09.15. 
syariah dan fikih. Satu lagi istilah yang juga terkait dengan kajian hukum Islam adalah ushul fikih. ${ }^{2}$

Pada prinsipnya hukum Islam bersumber dari Wahyu Ilahi, yakni AlQur'an, yang kemudian dijelaskan lebih rinci oleh Nabi Muhammad SAW melalui Sunnah dan Haditsnya. Wahyu ini menentukan norma-norma dan konsep-konsep dasar Hukum Islam yang sekaligus merombak aturan atau norma yang sudah mentradisi di tengah-tengah masyarakat. Namun demikian, Hukum Islam juga mengakomodasi berbagai aturan dan tradisi yang tidak bertentangan dengan aturan-aturan dalam Wahyu Ilahi tersebut. ${ }^{3}$

Hukum Islam juga dapat didefinisikan sebagai aturan, patokan, kaidah undang-undang yang berasal dari Islam untuk kehidupan manusia secara menyeluruh. Hukum ini hanya berlaku didalam Islam, meskipun hukum Islam ini memuat sikap dan ketentuan hukum tetang sesuatu di luar Islam. Contohnya: Wajib melindungi keselamatan kafir dzimmi (non muslim) yang tidak memusuhi Islam berada di wilayah kekuasaan Islam (dari al-Islam) ${ }^{4}$

Secara umum, hukum dapat didefinisikan sebagai peraturan yang dibuat oleh penguasa atau adat yang berlaku bagi semua orang di suatu masyarakat, undang-undang, untuk mengatur pergaulan hidup manusia, patokan atau kaidah mengenai suatu peristiwa, keputusan yang ditetapkan oleh hakim. Penguasa dalam kaitan hukum adalah Tuhan, utusan-Nya (Nabi dan Rasul), para penguasa yang berwujud manusia seperti sultan, khalifah, dan raja dalam negara yang sistem pemerintahannya monarki. ${ }^{5}$

Dilihat dari segi ilmu hukum, syariat merupakan norma hukum dasar yang ditetapkan Alloh, yang wajib di ikuti orang Islam berdasarkan iman yang berkaitan dengan akhlak baik dalam hubungannya dengan Alloh maupun dengan sesama manusia dan benda dalam masyarakat. Norma hukum dasar ini dijelaskan dan atau dirinci lebih lanjut oleh Nabi Muhammad sebagai Rosul-Nya. Karena itu syariat terdapat di dalam AlQur'an dan kitab-kitab hadist. Menurut sunnah (al Qouliyah atau perkataan) Nabi Muhammad, umat Islam tidak akan pernah sesat dalam perjalanan

\footnotetext{
${ }^{2}$ Ibid.

${ }^{3}$ Ibid.

${ }^{4}$ Muhamad Farid Faq, Hukum Islam Pdf,dinus.ac.id/repository/docs/ajar/, hal.2, Rabu, 7 Maret 2018, 09.30.

${ }^{5}$ Ibid.
} 
hidupnya di dunia ini selama mereka berpegang teguh atau berpedoman kepada Al-Qur'an dan Sunnah Rosululloh. Dengan perkataan lain, umat Islam tidak akan pernah sesat dalam perjalalan hidupnya di dunia ini selama ia mempergunakan pola hidup, pedoman hidup, tolok ukur hidup, dan kehidupan yang terdapat dalam Al-Qur'an dan kitab-kitab Hadits yang Shohih (sahih: otentik, benar). Dalam Islam, pada masa Rosululloh tidak dijelaskan tata cara dan pendaftaran secara rinci. Akan tetapi yang dapat dipelajari dari tindakan Nabi ataupun sahabatnya atau hasilnya, pada masa itu belum dikenal perwakafan secara administrasi namun dalam urusan muamalah ada tuntunan al-Quran yang menganjurkan untuk menulis dan disaksikan dua orang saksi laki-laki. ${ }^{6}$ Maka pemerintah Indonesia membuat PP. Nomor 28 tahun 1977 sebagai implementasi terhadap ayat Alloh, dalam hal ini PP 28 tahun 1977 hanya mengatur wakaf tanah saja, belum mengatur wakaf non tanah, ${ }^{7}$ dan diperbarui lagi dengan PP 42 Tahun 2006 Tentang Pelaksanaan Undang-Undang No 41 tahun 2004 tentang wakaf.

Wakaf adalah sedekah yang paling mulia untuk menebarkan kebaikan kepada pihak yang memperoleh hasil wakaf dan orang yang membutuhkan bantuan, seperti fakir miskin, anak yatim, janda, orang yang tidak punya usaha dan pekerjaan atau orang yang berjihat di jalan Alloh SWT, untuk para pengajar dan penuntut ilmu, atau untuk pembantu dan untuk pelayanan kemaslatan umum. Wakaf merupakan amal kebajikan bagi pewakaf, karena menyedekahkan harta yang tetap utuh, tetapi pahalanya mengalir terus, sekalipun pewakafnya sudah putus usahanya, karena telah meninggal dunia. ${ }^{8}$

\section{B. METODE PENELITIAN}

Penelitian ini merupakan penelitian lapangan, yang dilakukan di Masjid Al Mukmin dan KUA Kecamatan Jatiyoso Kabupaten Karanganyar. Sumber data yang digunakan menggunakan wawancara, observasi, dan dokumentasi.

\footnotetext{
${ }^{6}$ Abdul Halim, Op. Cit., hal. 104.

${ }^{7}$ Ibid.

${ }^{8}$ Abu Mulzamah Al Jami', Op. Cit, hal.3.
} 


\section{HASIL DAN PEMBAHASAN}

Pengelolaan perwakafan tanah milik setelah Peraturan Pemerintah Nomor 28 Tahun 1977 telah dilakukan oleh Kementerian Agama yaitu: Pertama, mendata seluruh tanah wakaf hak milik di seluruh wilayah Tanah Air, pendataan tanah wakaf hak milik ini sebagai langkah untuk memastikan jumlah tanah wakaf di Indonesia untuk kemudian dijadikan tolak ukur pengelolaan, pemberdayaan, dan pembinaan tanah wakaf. Kedua, memberikan sertifikat tanah wakaf yang belum disertifikatkan, dan memberikan bantuan advokasi terhadap tanah wakaf yang bermasalah. ${ }^{9}$

Adapun proses sertifikasi tanah wakaf sesuai dengan Peraturan Pemerintah Nomor 28 Tahun 1977:

1. Calon Wakif bersama saksi, dan Nadzir datang menghadap Kepala KUA selaku Pejabat Pembuat Akta Ikrar Wakaf (PPAIW).

2. PPAIW memeriksa persyaratan wakaf dan selanjutnya mengesahkan Nadzir.

3. Wakif mengucapakan Ikrar Wakaf di hadapan saksi-saksi, untuk selanjutnya PPAIW membuat Akta Ikrar Wakaf (AIW) dan salinannya.

4. PPAIW atas nama Nadzir datang ke Kantor Agraria Kabupaten membawa berkas permohonan pendaftaran tanah wakaf dengan pengantar formulir W.7.

5. Kantor Agraria menyerahkan sertifikat tanah wakaf kepada Nadzir, dan selanjutnya ditunjukkan kepada PPAIW untuk dicatat pada Akta Ikrar Wakaf W-4.

Sedangkan tata cara pelaksanaan perwakafan dan pendaftaran tanah wakaf adalah sebelum melaksanankan ikrar wakaf dihadapan pejabat pembuat akta ikrar wakaf (PPAIW) seorang wakif harus lebih dulu melakukan hal-hal sebagai berikut:

1. Mencari surat keterangan dari Kepala Desa/ Kelurahan tentang kebenaran tanah tersebut adalah wakaf dan tidak dalam sengketa, yang diperkuat oleh Kecamatan setempat.

2. Ijin dari Bupati/ Walikotamadya Kepala Daerah cq. Kepala Direktorat Agraria setempat. ${ }^{10}$

${ }^{9}$ Dirjen Bimas Islam, Op. Cit, hal. 137.

${ }^{10}$ Ibid., hal. 138. 
Setelah wakif telah melakukan hal-hal tersebut diatas, maka wakif datang ke KUA selaku pegawai Pembuat Akta Ikra Wakaf (PPAIW) dengan membawa dan menyerahkan syarat-syarat perwakafan tanah milik yang sudah ditetapkan oleh PPAIW Kecamatan Jatiyoso. Adapun syarat-syarat itu sebagai berikut:

1. Surat keterangan ikrar wakaf bermaterai $6000(\mathrm{~W}-1)$.

2. Surat keterangan para ahli waris/ anaknya bermateri 6000 .

3. Membawa bukti kepemilikan tanah (sertifikat) asli.

4. Surat pengesahan nadzir wakaf desa yang bersangkutan oleh Kepala KUA. setempat (bentuk W-5).

5. Fotocopy pelunasan pajak bumi dan bangunan tahun yang bersangkutan (rangkap 2).

6. Fotocopy KTP wakif (rangkap 2).

7. Fotocopy KTP nadzir (rangkap 2).

8. Fotocopy KTP saksi (2 saksi).

9. Menyediakan materai 6000an sebanyak 4 lembar.

10. Mengisi dan menandatangani blangko-blangko wakaf dari badan pertanahan nasional (BPN) maupun dari KUA selaku PPAIW. ${ }^{11}$

Ketantuan-ketentuan lain yang menjadi persyartan dalam pelaksanaan perwakafan tanah milik di Kecamatan Jatiyoso adalah masalah pernyataan keterangan akta ikrar wakaf oleh wakif harus di hadapan PPAIW setempat dan harus disaksikan 2 orang saksi, serta nadir yang ditunjuk. Dalam Peraturan Menteri Agama Nomor 1 Tahun 1978 tentang Pelaksanaan Peraturan Pemerintah No 28 Tahun 1977 Tentang Perwakafan telah diatur bahwa kepala KUA ditunjuk sebagai PPAIW dan admisistrasi perwakafan diselenggarakan oleh KUA Kecamatan, adapun tugas pejabat pembuat akta ikrar wakaf adalah sebagai berikut:

1. Meneliti kehendak wakif.

2. Meneliti dan mengesahkan nadzir atau anggota nadzir.

3. Meneliti saksi ikrar wakaf.

4. Manyaksikan pelaksanaan ikrar wakaf.

5. Membuat akta ikrar wakaf.

6. Menyampaikan akta ikrar wakaf dan salinannya kepada pihak-pihak terkait.

7. Menyimpan lembar pertama (asli) akta ikrar wakaf (AIW).

\footnotetext{
${ }^{11}$ Ibid., hal. 139.
} 
8. Menyimpan dan memelihara akta ikrar wakaf dan daftarnya.

9. Mengurus pendaftaran wakaf.

10. Mengajukan permohonan kepada kantor Badan Pertanahan Nasional (BPN) kabupaten /kotamadya setempat untuk mendaftarkan wakaf tanah milik yang dilampiri:

a. Sertifikat tanah yang bersangkutan.

b. Akta Ikrar Wakaf (AIW).

c. Surat pengesahan nadzir. ${ }^{12}$

Setelah itu BPN mengadakan pengukuran tanah wakaf tersebut yang disaksikan oleh pihak-pihak yang terkait yaitu nadzir, wakif, 2 orang saksi, dan lain-lain. Setelah pengukuran selesai BPN memproses perwakafan tanah tersebut 2 bulan setelah pengajuan wakaf ke BPN. Dalam pelaksanaan ikrar wakaf, pejabat pembuat akta ikrar wakaf membuat akta ikrar wakaf dan salinannya. Adapun akta ikrar wakaf dibuat rangkap tiga:

1. Lembar pertama disimpan oleh Pegawai Pembuat Akta Ikrar Wakaf.

2. Lembar kedua dilampirkan pada surat permohonan pendaftaran kepada Bupati/Walikota Kepala Daerah cq. Kepala Subdit Agraria atau BPN setempat.

3. Lembar ketiga dikirim ke Pangadilan Agama yang mewilayahi tanah wakaf tersebut. ${ }^{13}$

Adapun salinan akta ikrar wakaf rangkap empat:

a) Salinan lembar pertama disampaikan kepada Wakif.

b) Salina lembar kedua disampaikan kepada Nadzir.

c) Salina lembar ketiga disampaikan kepada Kantor Kementerian Agama setempat.

d) Salian lembar keempat dikirim kepada Kepala Desa yang mewilayahi tanah wakaf setempat. ${ }^{14}$

Untuk menyelesaikan pendaftaran dan pencatatan perwakafan tanah di Kecamtan Jatiyoso tidak dikenai biaya kecuali untuk membeli materai. Jika suatu bidang tanah diwakafkan sebagian, maka oleh calon wakif terhadap bidang tanah tersebut harus dilakukan pemisahan terlebih dahulu atas bagian-bagian yang tidak diwakafkan dan bagian yang akan diwakafkan. Pemisahan itu tetap atas nama calon wakif, dan biaya-biaya yang berkenaan

${ }^{12}$ Ibid., hal. 139.

${ }^{13}$ Ibid., hal. 143.

${ }^{14}$ Ibid., hal. 144. 
dengan pemisahan tersebut di atas pendaftaran untuk pertama kali ditanggungkan kepada wakif.

\section{KESIMPULAN}

Proses sertifikasi tanah wakaf milik Masjid Al Mukmin Wilayah Kantor Urusan Agama Kecamatan Jatiyoso, Kabupaten Karanganyar, sudah sesuai dengan Peraturan Pemerintah No 28 Tahun 1977:

1. Calon wakif bersama saksi dan nadir datang menghadap kepala KUA selaku pejabat Pembuat Akta Ikrar Wakaf (PPAIW).

2. PPAIW memeriksa persyaratan wakaf dan selanjutnya mengesahkan nadzir.

3. Wakif mengucapkan ikrar dihadapan saksi-saksi, untuk selanjutnya PPAIW membuat Akta Ikrar Wakaf (AIW) dan salinannya.

4. PPAIW atas nama Nadzir datang ke kantor pertanahan Kabupaten membawa berkas permohonan perdaftaran tanah wakaf dengan pengantar formulir W.7.

5. Kantor pertanahan memproses sertifikasi tanah wakaf.

6. Kepala kantor pertanahan menyerahkan sertifikat tanah wakaf kepala nadzir, dan selanjutnya ditunjukkan kepada PPAIW untuk dicatat pada Akta Ikrar Wakaf W.4.

Mekanisme pelaksanaan perwakafan tanah milik masjid Al-Mukmin di Dusun Karang, Desa Karangsari, Kecamatan Jatiyoso, Kabupaten Karanganyar sudah sesuai dengan Hukum Islam. Hal ini terbukti ketika penulis berbicara langsung dengan kepala KUA Kecamatan Jatiyoso selaku PPAIW. Ketika itu, beliau PPAIW menjelaskan bahwa pelaksanaan perwakafan di Kecamatan Jatiyoso sudah sesuai dengan Hukum Islam yaitu mengenai syarat dan rukun dalam perwakafan. Unsur wakaf menurut pakar Hukum Islam harus memenuhi 4 unsur sebagai mana disepakati oleh jumhur Ulama, adapun ke-empat unsur tersebut adalah sebagai berikut:

1. Wakif adalah pihak yang menyerahkan wakaf.

2. Nadzir adalah pihak yang diserahi wakaf.

3. Benda yang diwakafkan. 
4. Sighot adalah penyataan penyerahan wakaf.

Mengingat arti pentingnya perwakafan tanah milik tersebut bagi pengembangan kehidupan keagamaan maka harus dilaksanakan dengan sebaik-baiknya sesuai dengan Peraturan Pemerintah No 42 Tahun 2006 Tentang Perwakafan Dan Undang-Undang No 41 Tahun 2004, Tentang Wakaf, Dan Peraturan Menteri Dalam Negeri No 6 Tahun 1977 tentang cara pendaftaran tanah dan mengenai perwakafan tanah milik, kemudian Peraturan Menteri Agama Republik Indonesia No 1 Tahun 1979 tentang pelaksanaan Peraturan Pemerintah No 28 Tahun 1977 tentang perwakafan tanah milik.

Dalam pasal 9 dari Peraturan Pemerintah No 28 Tahun 1977 mengharuskan perwakafan secara tertulis tidak cukup hanya dengan ikrar lisan saja. Tujuannya adalah untuk memperoleh bukti yang otentik yang dapat digunakan untuk berbagai persoalan seperti untuk bahan-bahan pendataan pada kantor sub direktorat agraria kabupaten / kotamadya, dan untuk keperluan penyelesaian sengketa yang mungkin timbul di kemudian hari tentang tanah yang di wakafkan. Adanya keharusan wakif yang melakukan ikrar wakaf dengan cara tertulis ini kenyataannya sudah dilaksanakan oleh para pihak yang mewakafakan tanah milik di Kecamatan Jatiyoso, Kabupaten Karanganyar.

Sesuai dengan Ketentuan Pasal 18 Peraturan Menteri Agama Nomor 1 Tahun 1978 maka penyelesaian administrasi perwakafan tanah milik yang di atur dalam peraturan ini dibebaskan dari biaya kecuali biaya meterai. Kenyataannya di KUA Kecamatan Jatiyoso selaku PPAIW tidak memungut biaya kecuali para pihak yang mewakafkan tanahnya hanya dibebani biaya materai. Ini berarti mekanisme tatacara yang sudah diatur dalam Peraturan Pemerintah No 28 Tahun 1977 dan beragai peraturan pelaksanaan lainnya sebagian besar sudah dilaksanakan oleh para pihak yang mendaftarkan tanah miliknya untuk diwakafkan kepada pihak lain. Dengan demikian pelaksanaan perwakafan tanah milik yang diatur dalam Peraturan Pemerintah No 28 Tahun 1977 itu sudah sesuai dengan aturan dalam hukum Islam yaitu ada wakif, nadzir, benda yang diwakafkan, serta ikrar wakaf/sighot. 


\section{REFERENSI}

Abdurrohman, Masalah Perwakafan Tanah Milik dan Kedudukan Tanah Wakaf Di Negara Kita, Bandung: Citra Aditya Abadi, 1990, Cet 3.

Abror.K “BAB_III. Metode Penelitian”Http://www.eprints.undip.ac.id /40779/3/pdf.

Alfiah, Nur, Siti, "Sumber Hukum Islam", http://www.kolaynf.blogspot.com /2016/05/

makalah-pengertian-sumber-dan-fungsi.html, Wordpress.Com.

Arikunto, Suharsimi, Dkk, Penelitian Tidakan Kelas, Jakarta: Bumi Aksara, 2007, Cet. 4.

Arikuto, Suharsimi, Prosedur Penelittian Suatu Pendekatan Praktik, Jakarta: Rineka Cipta, 2002, Cet. 15.

Bahreisj, Salim ,Terjemah Riadus Shalihin I, Bandung: Al-Ma'arif, 1987, Cet. 10.

Bisri, Hasan, Cik, (at.al), Kompilasi Hukum Islam dan Peradilan Agama Dalam Sistim Hukum Nasional, Jakarta: Logos Wacana Ilmu, 1999, Cet. 2

Direktorat Jendral Bimas Islam dan Pemberdayaan Haji, Fiqih Wakaf, Jakarta: Departemen Agama, 2004

Dirjen Kelembagaan Agama Islam, Kompilasi Hukum Islam di Indonesia, Depag RI, 1991/1992, Cet. 3.

Dokumentasi, Data KUA Jatiyoso, 2017.

Halim, Abdul, Hukum Perwakafan di Indonesia, Ciputat: Ciputat Press, Cet. I.

Kamus Besar Bahasa Indonesia Online,http://www.kbbi. kata.web.id. /kamus Bahasa Indonesia.

Kementerian Agama RI, Himpunan Perundang-Undangan Tentang Wakaf, Garazawa, Kementerian Agama Kabupaten Karanganyar, 2012.

Proyek Peningkatan Sarana Keagamaan Islam, Zakat dan Wakaf, Himpunan Peraturan Perundang-Undangan Perwakafan Tanah Milik, Jakarta: Departemen Agama, 1995/1996.

Proyek Peningkatan Zakat Dan Wakaf Dierjen Bimas Islam Dan Penyelenggaraan Haji, Penduan Pemberdayaan Tanah Wakaf Produktif Strategis di Indonesia, Jakarta: Departemen Agama Repiblik Indonesia, 2003.

Rosjid, Sulaiman, Fiqih Islam, Bandung: Sinar Baru, 1990.

Sabiq, Sayyid, Fiqih Sunnah 3, Bandung: Al Ma'arif, 1986.

Saputra, Imam, Heri, "Shoheh Bukhori " http:// www.belajarIslamsunnah. com /2016/09/download-kitab-hadits-shahih-muslim.html.

Sekretaris Jendral MPR RI, Undang-Undang Dasar Negara Republik Indonesia Tahun 1945, Jakarta, 2011. 
ACADEMIA: Jurnal Ilmu Sosial dan Humaniora, Vol. 2 No 1 Agustus 2019

Soenarjo, Dkk. Al-Qur'an Dan Terjemahnya, Semarang: CV Toha Putra, 1989

Suprayogo, Imam, Metodologi Penelitian Sosial-Agama, Bandung: Remaja Rosdakarya Offset, 2003, Cet. 2. 